\title{
Estimation of Serpa cheese ripening time using multiple linear regression (MLR) considering rheological, physical and chemical data
}

\author{
Nuno Alvarenga ${ }^{1, *}$, Paula Silva ${ }^{1}$, José Rodriguez Garcia ${ }^{2}$ and Isabel Sousa ${ }^{2}$ \\ ${ }^{1}$ Instituto Politécnico de Beja - Escola Superior Agrária, Rua Pedro Soares, Apartado 6158, 7801-908 Beja, Portugal \\ ${ }^{2}$ Technical University of Lisbon, Instituto Superior de Agronomia, DAIAT, Tapada de Ajuda, 1349-017 Lisboa, Portugal
}

Received 14 March 2007; accepted for publication 5 February 2008

\begin{abstract}
Raw ewes' milk semi-soft cheeses (RESS-cheeses) are important products in Portugal and in several European regions. Creamy texture is an essential attribute of these cheeses, which results from structural properties that are not always well characterized. Here, the structural changes occurring during the ripening period of a traditional RESS-cheese, known as Serpa cheese, were analysed through small amplitude oscillatory shear (SAOS). Rheological data was complemented with other physical and chemical parameters, that were monitored during ripening, in order to estimate Serpa cheese ripening time using multiple linear regression (MLR). Mechanical spectra indicated a relatively strong structure, comparable to a gel, with a low dependence on frequency at the beginning of ripening and a weak structure, comparable to a concentrated suspension, with a crossing point $\left(\mathrm{G}^{\prime \prime}=\mathrm{G}^{\prime}\right)$ at the left of the graphic and with both moduli highly dependent on frequency, at the end of ripening. Good correlations $(P<0 \cdot 05)$ were obtained between structural (hardness and storage modulus) and proteolysis indicators. Using a combination of chemical, colour and rheological parameters we were able to obtain a multiple linear regression (MLR) which allows the estimation of Serpa cheese ripening time with an estimation error of $1 \cdot 7 \mathrm{~d}$ (adjusted $\mathrm{R}^{2}=0 \cdot 98, P<0 \cdot 0001$ ).
\end{abstract}

Keywords: ewe cheese, multiple linear regression, estimation, ripening, rheology, proteolysis.

Raw ewes' milk semi-soft cheese (RESS-cheese) constitutes an important manufactured product in Portugal, with high added value. Serpa is one of the most appreciated Portuguese RESS-cheeses and it is produced in the south eastern region of Portugal. It is a creamy, fat and semi-soft cheese, originated from a slow curd syneresis after coagulation with a vegetable rennet infusion (Cynara cardunculus L.) (Roseiro et al. 2003a). Because Serpa cheese is made from raw ewes' milk, on traditional farms, a minimum ripening period of $30 \mathrm{~d}$ is necessary to ensure food safety. The production of lactic acid during this ripening period reduces the $\mathrm{pH}$, improves whey expulsion from the curd, affects cheese flavour and inhibits the growth of the pathogenic bacteria. This is one of the several control methods available to the cheesemaker to prevent disease outbreaks caused by cheese (Zottola \& Smith, 1991). Therefore, Serpa cheese can only be sold after this period, which is required to fulfil Serpa cheese Appellation of Origin regulation

*For correspondence; e-mail: bartolomeu.alvarenga@esab. ipbeja.pt
(Portuguese legislation). For these safety reasons, the estimation of the ripening time, i.e., how many days of ripening the cheese has undergone during maturation (cheese age), has recently become an important issue, since cheeses do not display the manufacture date (Pinho et al. 2004; Poveda et al. 2004; Ferreira et al. 2006).

For consumers, the most important feature of RESS cheeses is the creamy mouth feel attribute. The structural properties of cheese can be described by its viscoelastic behaviour and are mostly dictated by the properties of the continuous network formed by the protein crosslinks. Other important cheese constituents that contribute to the overall viscoelastic behaviour, while modifying the properties of the protein network, are fat and moisture (Zalazar et al. 2002). Measurements using small amplitude oscillatory shear (SAOS) allow the quantification of the elastic and viscous contributions to the cheese properties. Elastic response in cheese is primarily due to the protein-protein bonds. In contrast, the viscous dissipation in cheese may be due to the lubrication effect of fat on this matrix material (Park, 2007). 
Cheese texture is affected by factors that determine structure, such as milk composition, moisture content, salt, $\mathrm{pH}$ and degree of proteolysis during ripening (Da Cunha et al. 2006). Proteolysis is the most complex of these events and, possibly, the most important in the flavour and texture development (Sousa et al. 2001). Cheese textural changes during ripening results in smoothing and softening, due to a prevalence of proteolysis of the $\alpha_{\mathrm{s} 1}$-casein (Al-Otaibi \& Wilbey, 2006), or hardening, when the drying process dominates (Awad, 2006). These opposing effects on the rheological properties of the cheese were explained by Dewettinck et al. (1999): proteolysis reduces the storage modulus while drying has the opposite effect. However, it is well established that cheese softening, induced by proteolysis, prevails when cheese is made from raw milk (Rosenberg et al. 1995).

Little is known about the physical and biochemical mechanisms that underline the ripening process of the traditional Serpa RESS-cheese. Therefore, the aims of this study were: (i) to monitor the structural changes of Serpa RESS-cheeses during ripening, considering a range of rheological (mechanical spectrum $-\mathrm{G}_{1 \mathrm{~Hz}}^{\prime} \tan \delta_{1 \mathrm{~Hz}} \log$ $\alpha$ and $b$; texture analysis parameters - hardness and adhesiveness), colour ( $\mathrm{L}^{*}, \mathrm{a}^{*}$ and $\left.\mathrm{b}^{*}\right)$ and chemical parameters (moisture, fat, acidity, $\mathrm{pH}$, total nitrogen, water soluble nitrogen, non-protein nitrogen and amino acidic nitrogen), and (ii) to develop a multiple linear regression model that will allow the estimation of the duration of the ripening period (cheese age), using chemical, colour an rheological data. In this study, the use of cheeses manufactured by two different producers was studied to overcome the variability inherent in an essentially traditional process.

\section{Materials and methods}

\section{Cheese samples}

For this study, two producers were selected for sample collection on the basis of the quality and regularity of their Serpa cheese production. Cheeses were manufactured from slow curd syneresis, after raw ewes' milk coagulation $\left(30{ }^{\circ} \mathrm{C} / 45 \mathrm{~min}\right)$ with a Cynara cardunculus L. infusion. The curd was pressed and subjected to $42 \mathrm{~d}$ ripening, performed in two successive controlled rooms: two weeks of ripening performed in a controlled temperature $\left(8-9{ }^{\circ} \mathrm{C}\right)$ and relative humidity (92-97\%) room and, afterwards, in a second ripening room, at $10-13{ }^{\circ} \mathrm{C}$ and at $85-90 \%$ relative humidity (Roseiro et al. 2003b). From each producer, samples were collected at different ripening stages. At producer 1, groups of 2 cheeses were picked after $0,7,14$, 21, 28 and $35 \mathrm{~d}$ ripening. At Producer 2, groups of 2 cheeses were picked after $0,3,7,14,21,28,35$ and $42 \mathrm{~d}$ ripening. Cheese samples were sent to the laboratory in refrigerated boxes and analysis started on the same day. One $\mathrm{cm}$ layer of the upper surface of each cheese was removed in order to expose a homogeneous surface of the inside allowing colour, $\mathrm{pH}$ and texture determinations. Furthermore, a cheese portion (approximately $0 \cdot 15 \mathrm{~kg}$ ) was removed and conserved $\left(4^{\circ} \mathrm{C}\right)$ in a Petri dish to be used for the rheometer determinations.

\section{Dynamic rheology}

Rheological measurements were performed at $20 \pm 1{ }^{\circ} \mathrm{C}$ using a controlled-stress Rheometer RS-75 (Haake, Germany), with a serrated parallel plate geometry of $20 \mathrm{~mm}$ diameter, in order to prevent slippage (Rosenberg et al. 1995). A stress sweep determination was performed on a different aliquot to ascertain linearity. The mechanical spectrum (frequency sweeps) was performed on another aliquot of the same sample at a constant shear stress of $200 \mathrm{~Pa}$ (samples of 0-14 d) and at $50 \mathrm{~Pa}$ (samples of 21-42 d). All frequency sweeps were conducted with oscillation frequencies ranging from 0.001 to $100 \mathrm{~Hz}$ in three different samples (triplicate). The output of the rheometer measurements was the variation of storage modulus $\mathrm{G}^{\prime}(\mathrm{Pa})$, loss modulus $\mathrm{G}^{\prime \prime}(\mathrm{Pa})$, loss tangent $\tan \delta\left(\mathrm{G}^{\prime \prime} / \mathrm{G}^{\prime}\right)$ and complex viscosity $\left|\eta^{*}\right|$ (Pa.s), as a function of the frequency $\mathrm{f}(\mathrm{Hz})$. From the later, $\log \alpha$ and $b$ values were obtained by logarithmic fitting of experimental data to the Power Law, according to eqn (1) (Kasapis et al. 1997):

$\left|\eta^{*}\right|=\alpha \cdot f^{-b} \quad$ or $\quad \log \left|\eta^{*}\right|=\log \alpha-b \log f$

The $\log \alpha$ value is a function of the viscoelastic proprieties that depend on the material consistency while the $b$ value reflects the dependency of viscoelastic properties on the frequency variation.

\section{Texture analysis}

A texture analyser TAHDi (Stable Micro Systems, Godalming, UK), equipped with a $250 \mathrm{~N}$ load cell, was used to perform the texture analysis at $20 \pm 1{ }^{\circ} \mathrm{C}$. The procedure was implemented by puncture with a $20 \mathrm{~mm}$ diameter aluminium cylindrical probe, at a penetration depth of $20 \mathrm{~mm}$ (the height of the sample was $50 \mathrm{~mm}$ ), with a crossed speed of $1 \mathrm{~mm} \mathrm{~s}^{-1}$. Texture measurements were performed in triplicate: one was performed in the core and the two others were performed in the rind of the cheese. From the force vs. time texturograms, two parameters were obtained: hardness and adhesiveness (VanHekken et al. 2005).

\section{Colour measurement}

The colour analysis was performed using a colorimeter CR 300 (Minolta, Osaka, Japan). The $\mathrm{L}^{*}, \mathrm{a}^{*}$, and $\mathrm{b}^{*}$ colour measurements were determined according to the CIELAB colour space, using a standard white tile $\left(L^{*}=97 \cdot 10\right.$, $a^{*}=-4 \cdot 88, b^{*}=7 \cdot 04$ ) for calibration (Pinho et al. 2004). Colour measurements were repeated ten times: five measurements in the core and another five in the rind of the cheese. 


\section{Chemical characterization}

Titrable acidity, moisture content and total nitrogen (TN) were determined according to AOAC (1990) methods. In addition, $\mathrm{pH}$ was measured using a penetration electrode (Metrohm, Switzerland) and fat content through the Van Gulik method (ISO 3432, 1975). Water soluble nitrogen (WSN) was quantified performing an aqueous extraction of the N-components (Kuchroo \& Fox, 1982), followed by nitrogen determination using the micro-Kjeldahl method using a Kjeltec System 1030 distilling+titration unit system (Tecator, Höganäs, Sweden). Non-protein nitrogen (NPN) was determined by the $\mathrm{N}$-component precipitation with a trichloroacetic acid solution $\left(1 \cdot 2 \mathrm{~g} \mathrm{~kg}^{-1}\right)$ and $\mathrm{N}$ determination of the filtrate (filter paper Whatman No. 42) using the micro-Kjeldahl method (Freitas et al. 1997). Aminoacidic nitrogen (AN) was determined by the ninhydrin method (Pearce et al. 1988). All chemical analyses were performed in triplicate.

\section{Statistical treatment of data}

The average, standard deviation, and 0.95 confidence interval values were determined for each parameter. Experimental data were subjected to One-way ANOVA (pairwise comparison of means with Scheffé test), to correlation analysis and to principal component analysis (PCA), which will allow the evaluation of RESS-cheese changes during ripening. Estimation of Serpa cheese length of the ripening period was performed with a stepwise MLR, which combines the backward elimination and forward selection regression methods (Draper \& Smith, 1998). The level of significance, chosen for variable selection, was 0.05. Data were analysed using STATISTICA 6.0 (StatSoft, Tulsa, USA).

\section{Results and discussion}

\section{Structural and chemical monitoring}

Structural changes occurring during the ripening period of the traditional Serpa cheese were evaluated. Data (not shown) concerning the mechanical spectra and loss tangent profile (Fig. 1), indicated a relatively strong structure, comparable to a gel, with a low dependence on frequency, at the beginning of ripening period, especially in samples 0-21 d. However, the cheese got less and less structured to the end of ripening as can be observed in Fig. 1, by the increased dependence of $\mathrm{G}^{\prime}$ and $\mathrm{G}^{\prime \prime}$ on frequency after long periods of ripening, 28, 35 and $42 \mathrm{~d}$. The critical crossing point, $\mathrm{G}^{\prime}=\mathrm{G}^{\prime \prime}$, is well shown at $35 \mathrm{~d}$ and this is the spectre of a very weak gel, sometimes considered too weakly structured to form a gel, being usually found in emulsion systems (Franco et al. 1998). As expected, texture data were in agreement with the observed mechanical spectra: in the first $14 \mathrm{~d}$, the curves were characteristic of a soft solid with a fracture point in the first peak (Fig. 2) (Szczesniak, 1963). Subsequent curves for 21 and $28 \mathrm{~d}$

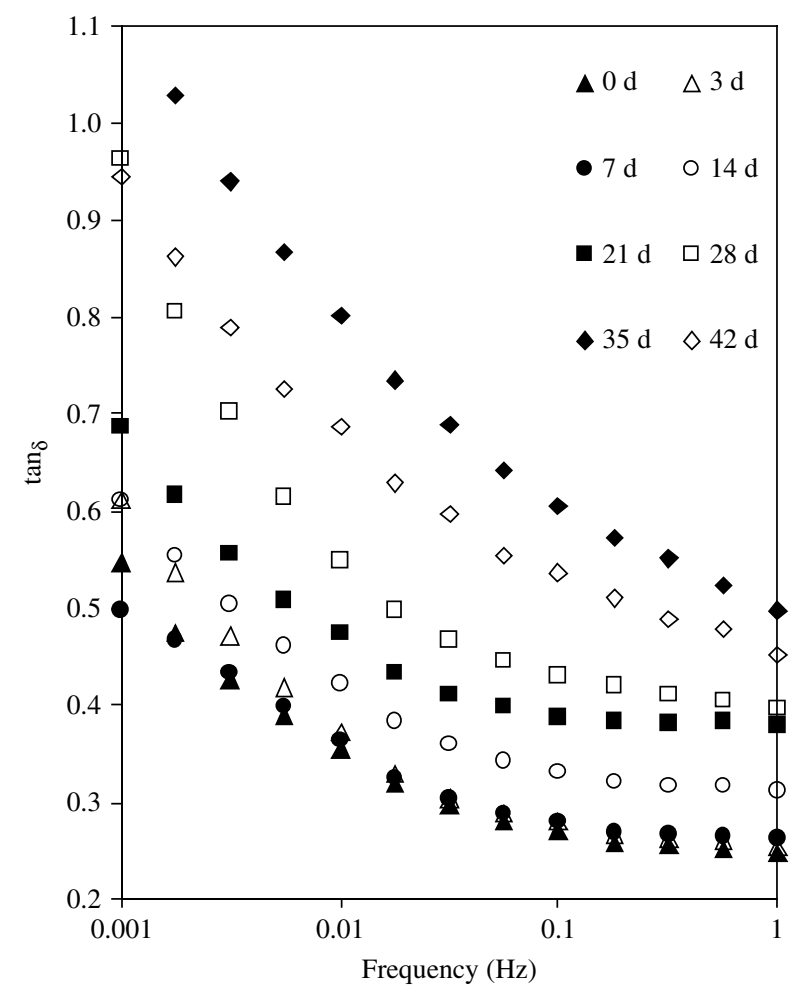

Fig. 1. Loss tangent profiles for samples with $0,3,7,14,21,28$, 35 and $42 \mathrm{~d}$ (producer 2, mean values, $n=6$ ).

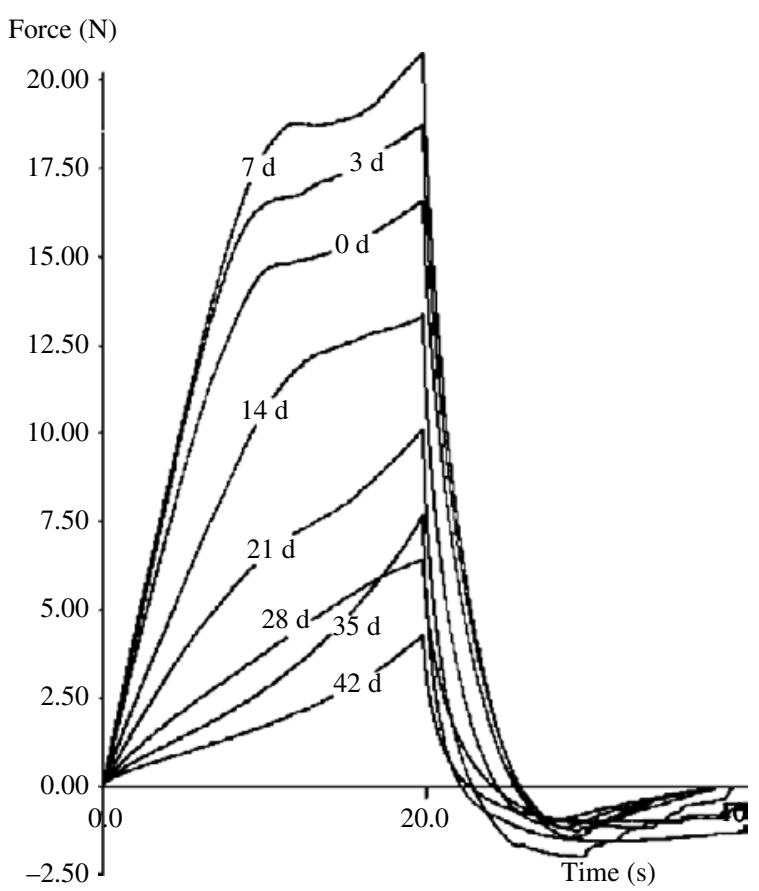

Fig. 2. Texture profile for samples with $0,3,7,14,21,28,35$ and $42 \mathrm{~d}$ (producer 2, mean values, $n=6$ ).

showed a small shoulder as a consequence of smooth texture and, further ripening time (35 and $42 \mathrm{~d}$ ), showed the typical profile for a highly viscous fluid under penetration. 

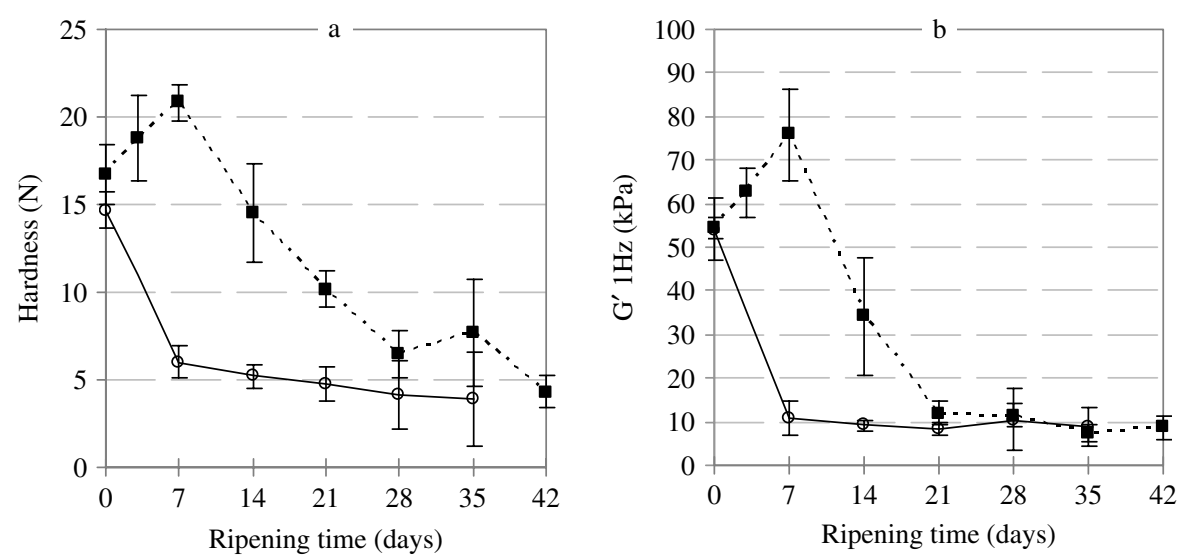

Fig. 3. Changes in the hardness (a) and storage modulus (b) for the producer $1(-\bigcirc-)$ and producer $2(---\mathbf{a}--)$ during ripening. $\mathrm{Y}$ error bars shows the $95 \%$ confidence level.

Hardness values decreased during ripening, from around $15 \mathrm{~N}$, at the beginning, to values around $5 \mathrm{~N}$ at the end of the ripening period $(P<0 \cdot 05$; Fig. $3 a)$. In the same manner, the storage modulus at $1 \mathrm{~Hz}$ changed from about $54 \mathrm{kPa}$ at the beginning to a value of around $10 \mathrm{kPa}$ $(P<0 \cdot 05)$, which remained stable until the end of ripening (Fig. 3b). However, in producer 2 these variables presented a slight increase at the beginning of the ripening process and a delayed decrease in hardness and $\mathrm{G}^{\prime} 1 \mathrm{~Hz}$. Nevertheless, at the end of the ripening period, hardness and storage modulus were similar for cheeses originated from both producers. According to the results observed in those figures, hardness and storage modulus can be considered as cheese structural indicators.

At the start of the study $(0 \mathrm{~d})$ cheeses from both producers presented similar structural indicators (Fig. 3). However, a delay in the ripening process was evident in the cheese of producer 2, which could be explained by the higher drying rate observed in the first week $(-0.31 \%$ moisture/day for producer 1 and $-0.51 \%$ moisture/day for producer 2 ; Fig. $4 \mathrm{a})$ and by the initial decrease verified in the proteolysis indicator NPN/TN\% (Fig. 4b). Roseiro et al. (2003a), studying RESS-cheeses, identified a proteolysis dependence during the production/ripening process. Therefore, differences in the ripening dynamics of raw ewes' milk cheeses seem to depend primarily on the quantity and quality of its natural enzymes which can, therefore, be considered main attributes of the raw milk quality (Tavaria et al. 2006).

The proteolysis indicators and $\mathrm{pH}$ showed a high correlation $(P<0 \cdot 05)$ among the structural indicators (Table 1$)$. In addition, the highest correlation observed was between hardness and NPN/TN $(-0.92)$, suggesting that proteolysis explained the Serpa cheese softening. The correlation between moisture and structural indicators was positive. If structural changes were influenced by the drying process, we could have expected a negative correlation between those properties. This means that the effect of drying, on the cheese structural changes, was overtaken by the $\mathrm{pH}$ and proteolysis effects. Taken together, these data and the information in Fig. 4a-e, suggest that softening of Serpa cheese is essentially characterized by an increase in proteolysis rate and a considerable $\mathrm{pH}$ decrease.

The $\mathrm{pH}$ profile was different in Serpa cheeses originated from the different producers (Fig. 4e). The minimum $\mathrm{pH}$ value was higher for cheeses coming from producer 1 $(\mathrm{pH} 5.4)$ compared with cheeses coming from producer 2 $(\mathrm{pH} 5 \cdot 1)$. Nevertheless, the final $\mathrm{pH}$ at the end of the ripening period was similar in cheeses of the two producers: $5 \cdot 7$ for producer 1 and $5 \cdot 6$ for producer 2 . Therefore, the main difference between cheeses originated from the two producers was the time taken to achieve the final $\mathrm{pH}$ rise: $28 \mathrm{~d}$ for producer 1 and 42 for producer 2 . In addition, due to lactose metabolism acidity increased during cheese ripening up to $\mathrm{d} 14$, and then decreased until the end of the ripening period (Fig. 4d). The falling $\mathrm{pH}$ (Fig. 4e) induced an effect of micelle demineralization (Ca bonds) and consequent dissociation, which were also responsible for cheese softening. This phenomenon causes a progressive dissociation of para $\kappa$ particles into small casein aggregates and, therefore, in the protein links of the cheese matrix (Ramkumar et al. 1998; Boutrou et al. 2002; Hassan et al. 2004). Therefore, a reduction of the solid-like properties can be observed in samples presenting low pHs (28-42 d; Fig. 1).

Finally, the evolution of cheese colour was monitored during the ripening period. The data, presented in Fig. 4g-i, revealed a decrease in luminosity and a slight increase in both greenness and yellowness during cheese ripening, a similar result has been reported (Pinho et al. 2004). In addition, the highest average values presented by the $b^{*}$ value in producer 1 could be connected to the higher fat content of their cheeses (Fig. 4f).

\section{Ripening dynamic using PCA approach}

PCA results, presented in Fig. 5, suggest that samples from the different producers showed differences in 

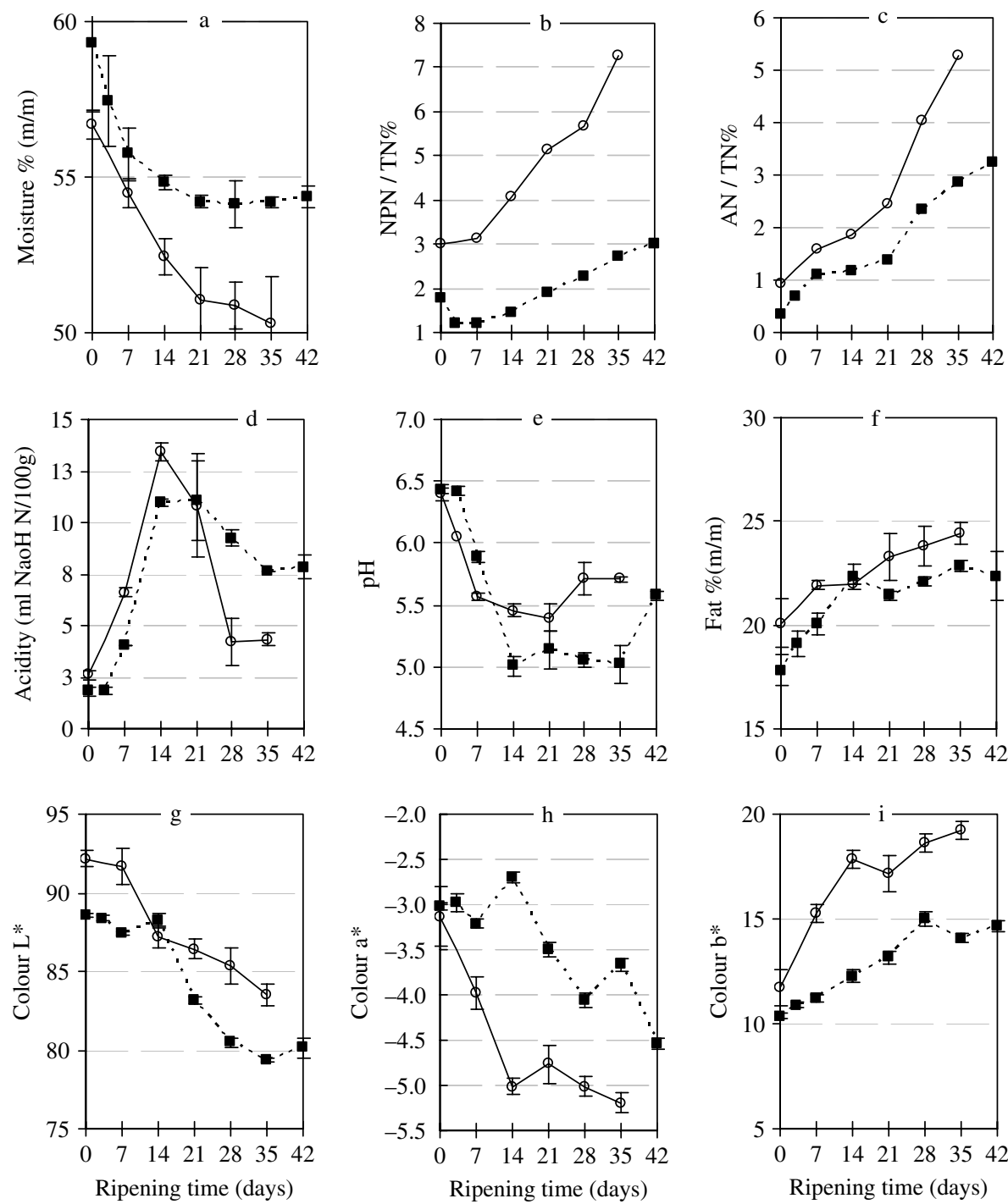

Fig. 4. Changes in: moisture (a), non-protein- $\mathrm{N}$ fraction (b), aminoacidic- $\mathrm{N}$ fraction (c), acidity (d), pH (e), fat (f) and colour parameters: $\mathrm{L}^{*}(\mathrm{~g}), \mathrm{a}^{*}(\mathrm{~h})$ and $\mathrm{b}^{*}(\mathrm{i})$ for the producer $1(-\bigcirc-)$ and producer $2\left(-\mathbf{-}_{---)}\right.$during ripening. $\mathrm{Y}$ error bars shows the $95 \%$ confidence level.

adhesiveness and luminosity. Samples from producer 1 were, in general, more luminous and less adhesive than those from producer 2 and these parameters were mostly explained by PC2. These were the main parameters that allow the differentiation of origin. In contrast, changes in Serpa cheese properties during ripening were mostly explained by PC1. For all parameters explained by this principal component, changes occurred faster at the beginning of the ripening process $(14 \mathrm{~d}$ for producer 1 and $21 \mathrm{~d}$ for producer 2), and slowed down progressively towards the end of ripening. This can be deduced from the relative distance among the plotted samples: large distances between $0 \mathrm{~d}$ and $14 \mathrm{~d}$ (producer 1) or $21 \mathrm{~d}$ (producer 2) samples, and shorter distances between the other samples collected at the end of the ripening. This higher rate of the biochemical reactions at the beginning
Table 1. Correlation results ( $\mathrm{r}$ ) and $P$ values between structural indicators (storage modulus and hardness) and proteolysis indicators (NPN/TN\% and NA/TN\%) and $\mathrm{pH}$

\begin{tabular}{lrlrrr} 
& \multicolumn{2}{c}{ Storage modulus $(\mathrm{Pa})$} & & \multicolumn{2}{c}{ Hardness $(\mathrm{N})$} \\
\cline { 2 - 3 } & \multicolumn{1}{c}{$r$} & $P$ & & $r$ & \multicolumn{1}{c}{$P$} \\
Moisture \% $(\mathrm{m} / \mathrm{m})$ & 0.724 & 0.042 & & 0.682 & 0.063 \\
NPN/TN\% & -0.836 & 0.010 & & -0.921 & 0.001 \\
NA/TN\% & -0.788 & 0.020 & & -0.878 & 0.004 \\
pH & 0.767 & 0.026 & & 0.654 & 0.079
\end{tabular}

of the ripening process may derive from the use of raw milk, as suggested by other authors (Rosenberg et al. 1995; Awad, 2006). 


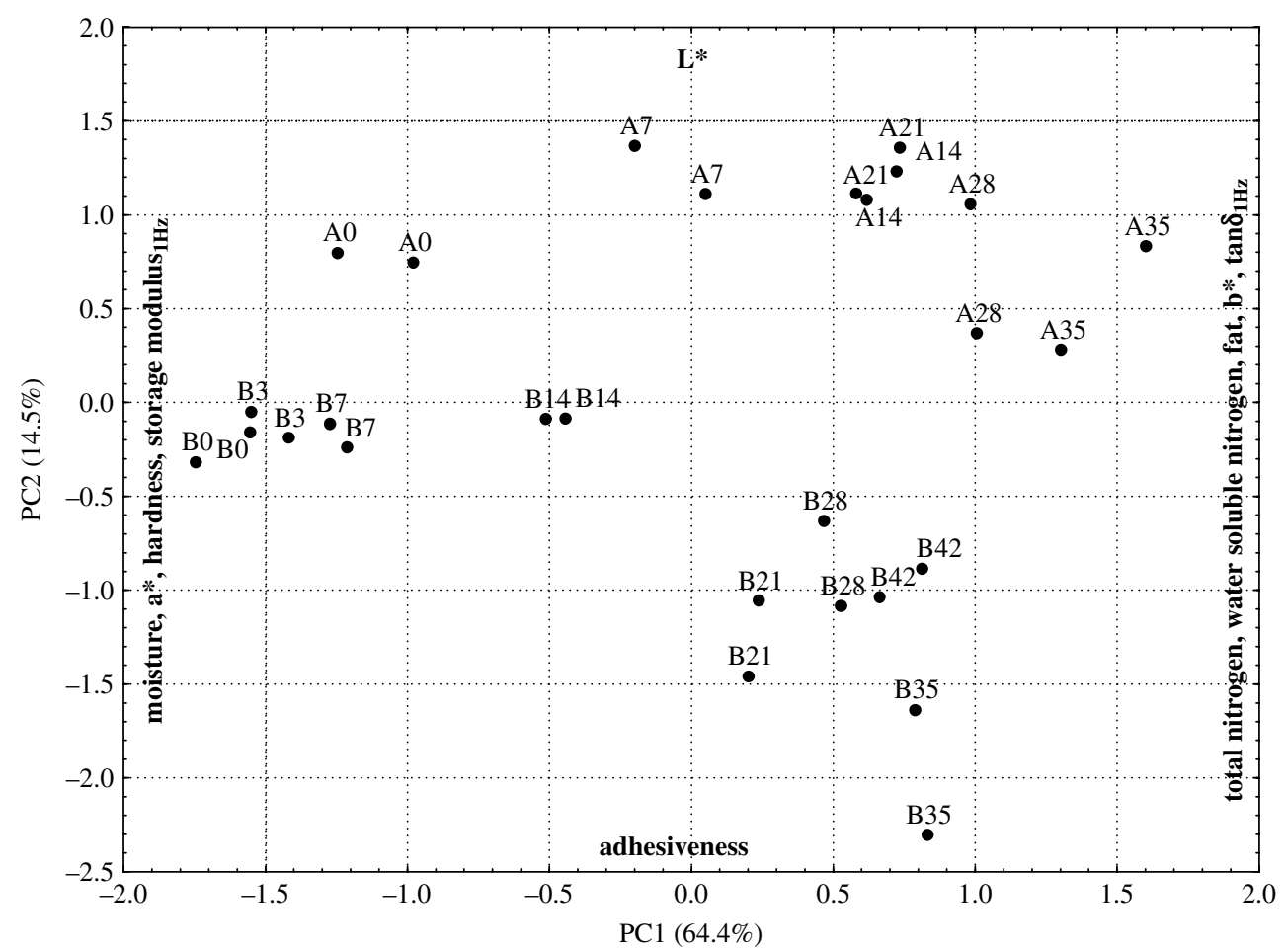

Fig. 5. PC1 vs. PC2 projection of samples. A0, A7, A14, A21, A28 and A35 are the samples of producer 1 with different ripening day times, and B0, B3, B7, B14, B21, B28, B35 and B42 are the samples of producer 2 with different ripening day times.

\section{Estimation of Serpa cheese ripening time}

A MLR analysis using the collected structural, chemical and colour data, was performed with the objective of developing a model that could allow the estimation of Serpa cheese ripening time (cheese age). This model might be useful to predict and guarantee food safety in Serpa Cheese. For this purpose, the model described by eqn (2), was followed (Draper \& Smith, 1998).

$\mathrm{Rt}=\beta_{0}+\beta_{1} \chi_{1}+\cdots+\beta_{\mathrm{n}} \chi_{\mathrm{n}}+\varepsilon$

In eqn (2), Rt represents ripening time, $\chi_{1} \ldots \chi_{\mathrm{n}}$ are structural, chemical, and colour parameters, $\beta_{0} \ldots \beta_{\mathrm{n}}$ represent model coefficients and $\varepsilon$ is the additive error term. The data demonstrated that ripening time (age of cheeses) could be estimated with the 8 parameters (SN/TN, AN/TN, $\mathrm{pH}, \mathrm{a}^{*}, \mathrm{~b}^{*}, \log \alpha, \mathrm{b}$ and $\left.\tan \delta_{1 \mathrm{~Hz}}\right)$. A graphical representation of the observed ripening time values vs. the predicted ripening time values was performed and it is presented in Fig. 6. The estimation of the cheese ripening period was performed for other types of ewes' milk cheeses using only chemical parameters based on quantification of protein fractions of $\alpha_{S_{1}}$-casein and $\alpha_{S_{1}-I}$ peptide. This ripening time prediction model showed an estimation error of $2.5 \mathrm{~d}$ (Ferreira et al. 2006), and this was the smallest value found. When only dry matter, $\mathrm{pH}$ and $\mathrm{a}_{\mathrm{w}}$ parameters were used, the prediction of the ripening period suffered an estimation error as high as $11.9 \mathrm{~d}$ (Poveda et al. 2004). Using both instrumental texture and colour

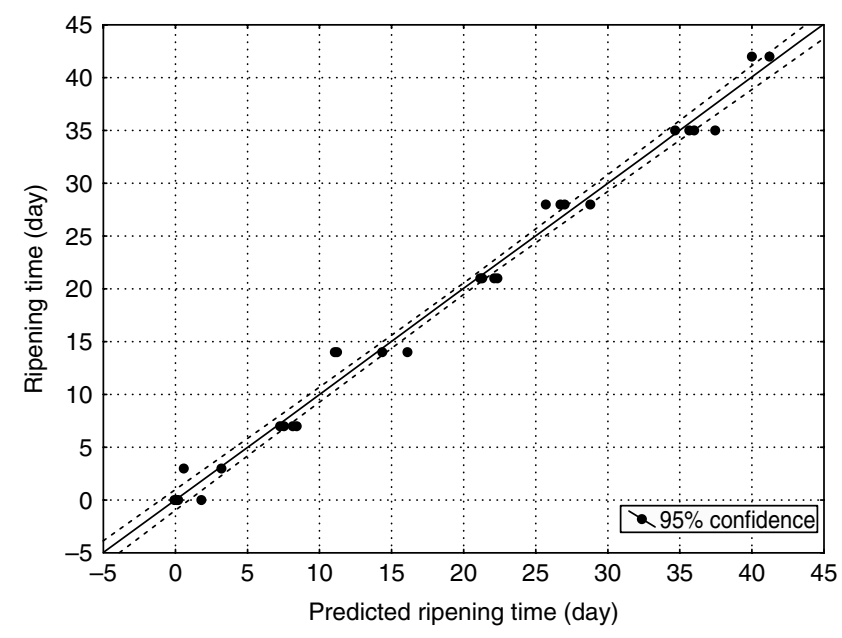

Fig. 6. Estimation of cheese ripening time.

parameters the error obtained forecasting ripening time was $4 \cdot 2 \mathrm{~d}$ (Pinho et al. 2004). In the present proposed model, observed in eqn (3), the estimation error was $1.74 \mathrm{~d}$ and the adjusted $R^{2}$ was $0.98(P<0 \cdot 0001)$. Therefore, using a combination of chemical, colour and rheological parameters we were able to obtain a MLR with a more satisfactory quality.

$$
\begin{aligned}
\mathrm{Rt}= & 218.93+0.92 \mathrm{SN} / \mathrm{TN}+8 \cdot 10 \mathrm{AN} / \mathrm{TN}-8 \cdot 86 \mathrm{pH}-11.40 \mathrm{a}^{*} \\
& -4.67 \mathrm{~b}^{*}-7.83 \log \alpha-123 \cdot 88 \mathrm{~b}-130.54 \tan \delta_{1 \mathrm{~Hz}}
\end{aligned}
$$


For safety reasons the model obtained in this study can assume a remarkable importance since, although it is not mandatory to display cheese age, it can be checked using the described approach. It is important to emphasize that this equation is valid only for Serpa Cheese and must be checked when an extrapolation to other RESS-cheeses is considered.

\section{Conclusion}

In this study a comprehensive analysis of several physical and biochemical parameters that characterize the ripening process of Serpa cheese was performed. Together the data suggest that from the several rheological parameters analysed, hardness and storage modulus were the most adequate indicators of the RESS-cheeses softening process during ripening. In addition, softening of Serpa RESScheeses occurring during ripening can be explained by changes in the protein network, such as the breakage of the protein-protein bonds, which occurred during proteolysis, and to the dissociation of sub-micelles caused by a $\mathrm{pH}$ decrease. Data presented here confirm that these processes occur mainly during the first 2-3 weeks of Serpa cheese ripening. Estimation of the ripening period, using 3 chemical, 2 colour and 3 rheological parameters, was possible with a standard error of $1.74 \mathrm{~d}$ and an adjusted $\mathrm{R}^{2}$ of $0.98 \quad(P<0.0001)$. In the future, this equation should be used to assess the safety of Serpa cheese; this product is obtained from raw ewes' milk and, therefore, should not be sold before completing at least 30 days of ripening.

\section{References}

Al-Otaibi MM \& Wilbey RA 2006 Effect of chymosin reduction and salt substitution on the properties of white salted cheese. International Dairy Journal 16 903-909

AOAC 1990 Official methods of analysis (15th edition). Washington: Association of Official Analytical Chemists

Awad S 2006 Texture and flavour development in Ras cheese made from raw and pasteurised milk. Food Chemistry 97 394-400

Boutrou R, Famelart M, Gaucheron F, Graet Y, Gassi J, Plot M \& Leonil J 2002 Structure development in a soft cheese curd model during manufacture in relation to its biochemical characteristics. Journal of Dairy Research 69 605-618

Da Cunha CR, Viotto WH \& Viotto LA 2006 Use of low concentration factor ultrafiltration retentates in reduced fat "Minas Frescal" cheese manufacture: Effect on composition, proteolysis, viscoelastic properties and sensory acceptance. International Dairy Journal 16 215-224

Dewettinck K, Deroo L, Messens W \& Huyghebaert A 1999 Dynamic rheological properties of Gouda cheese as influenced by age and position. Milchwissenschaft 54 258-262

Draper NR \& Smith H 1998 Applied regression analysis. New York: John Wiley

Ferreira IMPLVO, Veiros C, Pinho O, Veloso ACA, Peres AM \& Mendonca A 2006 Casein Breakdown in Terrincho Ovine Cheese:
Comparison with Bovine Cheese and with Bovine/Ovine Cheeses. Journal of Dairy Science 89 2397-2407

Franco J, Raymundo A, Sousa I \& Gallegos C 1998 Influence of processing variables on the rheological and textural properties of lupin proteinstabilized emulsions. Journal of Agricultural Food Chemistry $\mathbf{4 6}$ 3109-3115

Freitas AC, Fresno JM, Prieto B, Malcata FX \& Carballo J 1997 Effects of ripening time and combination of ovine and caprine milks on proteolysis of Picante cheese. Food Chemistry 60 219-229

Hassan AN, Corredig M, Frank JF \& Elsoda M 2004 Microstructure and rheology of an acid-coagulated cheese (Karish) made with an exopolysaccharide-producing Streptococcus thermophilus strain and its exopolysaccharide non-producing genetic variant. Journal of Dairy Research 71 116-120

ISO 34321975 Cheese - Determination of fat content - Butyrometer for Van Gulik method. International Organization for Standardization

Kasapis S, Paraskevopoulou A, Kiosseoglou A \& Alevipoulus S 1997 Small deformation properties of model salad dressing prepared with reduced cholesterol egg yolk. Journal of Texture Studies 28 221-237

Kuchroo CN \& Fox PF 1982 Soluble nitrogen in Cheddar cheese: comparison of extraction procedures. Milchwissenschaft 37 331-335

Park YW 2007 Rheological characteristics of goat and sheep milk. Small Ruminant Research 68 73-87

Pearce KN, Karahalios D \& Friedman M 1988 Ninhydrin assay for proteolysis in ripening cheese. Journal of Food Science 53 432-438

Pinho O, Mendes E, Alves MM \& Ferreira IMPLVO 2004 Chemical, physical and sensorial charateristics of "Terrincho" ewe cheese: Changes during ripening and intravarietal comparioson. Journal of Dairy Science 87 1-9

Poveda JM, Garcia A, Martin-Alvarez PJ \& Cabezas L 2004 Application of partial least squares (PLS) regression to predict the ripening time of Manchego cheese. Food Chemistry 84 29-33

Ramkumar C, Campanella OH, Watkinson PJ, Bennett RJ \& Creamer LK 1998 The effects of $\mathrm{pH}$ and time on rheological changes during early cheese maturation. Journal of Texture Studies 29 633-644

Roseiro LB, Garcia-Risco M, Barbosa M, Ames JM \& Wilbey RA 2003a Evaluation of Serpa cheese proteolysis by nitrogen content and capillary zone electrophoresis. International Journal of Dairy Technology 56 99-104

Roseiro LB, Wilbey RA \& Barbosa M 2003b Serpa cheese: Technological, biochemical and microbiological characterisation of a PDO ewe's milk cheese coagulated with Cynara cardunculus L. Lait 83 469-481

Rosenberg M, Wang Z, Chuang SL \& Shoemaker CF 1995 Viscoelastic property changes in Cheddar cheese during ripening. Journal of Food Science 60 640-644

Sousa MJ, Ardo Y \& McSweeney PLH 2001 Advances in the study of proteolysis during cheese ripening. International Dairy Journal $\mathbf{1 1}$ $327-345$

Szczesniak AS 1963 Classification of texture characteristics. Journal of Food Science 28 385-389

Tavaria FK, Reis PJM \& Malcata FX 2006 Effect of dairy farm and milk refrigeration on microbiological and microstructural characteristics of matured Serra da Estrela cheese. International Dairy Journal 16 895-902

Van-Hekken DL, Tunick MH \& Park YW 2005 Effect of frozen dtorage on the proteolytic and rheological properties of soft caprine milk Cheese. Journal of Dairy Science 88 1966-1972

Zalazar CA, Zalazar CS, Bernal S, Bertola N, Bevilacqua A \& Zaritzky N 2002 Effect of moisture level and fat replacer on physicochemical, rheological and sensory properties of low fat soft cheeses. International Dairy Journal 12 45-50

Zottola EA \& Smith LB 1991 Pathogens in cheese. Food Microbiology 8 $171-182$ 
Reproduced with permission of the copyright owner. Further reproduction prohibited without permission. 